\title{
Response to Deborah Willis's "The Black Civil War Soldier: Conflict and Citizenship"
}

Article

Accepted Version

King, N. (2017) Response to Deborah Willis's "The Black Civil War Soldier: Conflict and Citizenship". Journal of American Studies, 51 (2). pp. 331-338. ISSN 1469-5154 doi: https://doi.org/10.1017/S0021875817000482 Available at https://centaur.reading.ac.uk/70262/

It is advisable to refer to the publisher's version if you intend to cite from the work. See Guidance on citing.

To link to this article DOI: http://dx.doi.org/10.1017/S0021875817000482

Publisher: Cambridge University Press

All outputs in CentAUR are protected by Intellectual Property Rights law, including copyright law. Copyright and IPR is retained by the creators or other copyright holders. Terms and conditions for use of this material are defined in the End User Agreement.

\section{www.reading.ac.uk/centaur}

\section{CentAUR}

Central Archive at the University of Reading

Reading's research outputs online 
Nicole King, University of Reading

Journal of American Studies Forum

n.king2@reading.ac.uk

\section{Response to Deborah Willis's “The Black Civil War Soldier: Conflict and Citizenship”}

'The Black Civil War Soldier: Conflict and Citizenship' offers a stunning example of archival research.

Deborah Willis recovers voices not often heard in discussion of U.S. military history or African

American cultural studies. In her careful reading of multiple archives, and specifically photographs

and various written records, Willis also provides an example of how scholars might analyse the non-

print based components of archives. By connecting written and photographic records, Willis helps

to break a historical silence. She asserts that the voices and images given a platform in her work,

'create a balance of materials in order to grapple with this history that has often excluded a story

about bravery and black soldiers' (34). I agree that the co-presentation of written and photographic records provides a complex understanding of history that one or the other on its own could not. I

note that Willis reads the archive in such a way as to meld the individual and often domestic 'spaces'

of family letters that contain personal hopes and fears with the public 'spaces' of portraiture, journalism, and historiography. With references to my current research on African American World War II archives and from the poetry of Gwendolyn Brooks I use this space to assert that Willis's successful negotiation of these public and private realms of representation offers an excellent model for research on black soldiers in U.S. military conflicts and their quest for recognition and equal treatment as soldiers, citizens and people.

Willis excavates university archives, national archives, as well as archives located in historical societies and public libraries in order to present her readers with a deep understanding of the significance of photographs of black civil war soldiers. Her careful analysis of the photographs are given context with written records from the period and 'help us to understand what men in the nineteenth century thought about the war' and 'help us to imagine the period, by illustrating the 
triumphs and defeats of historical events' (Willis 18). Thus Willis makes excellent use of written and photographic narratives, even when they emanate from different sources. Her aim, to help the contemporary twenty-first century reader imagine the period, also suggests that the inevitable partiality of archives is not necessarily a hindrance to such projects of recovery. In Willis's hands the partiality becomes a creative opportunity: she helps her reader to intellectually collate these materials and she draws attention to the narratives told by individual photographs.

I was particularly struck by the narrative of 'worthiness' that Willis identifies and sees captured in some of the photographs she has included in her work. Thrust on to the world stage in the act of joining the armed forces, whether as free black men or as self-emancipators, Willis tells us that seeking the camera was a deliberate act for newly enlisted black soldiers, intent on standing shoulder to shoulder with their white counterparts. She writes:

One of their first gestures in proving their worthiness as soldiers and fighters was to stand in front of the camera and to be photographed, to be depicted as men who had made a choicea choice of freedom ... Whether standing alone, or in a group, they held flags, rifles, and banners, while looking directly in the camera lens - as if sending a message of undeniable patriotism. The visual narrative suggests their sense of commitment and courage (3-4). Such staging and effect is vividly conveyed in the image Willis includes by photographer Enoch Long which depicts an 'unidentified African American soldier in Union uniform with a rifle and revolver in front of painted backdrop showing weapons and American flag at Benton Barracks, St. Louis Missouri' sometime between 1863 and 1865.

Though the Benton Barracks soldier remains unidentified, other photographic subjects in Willis's essay are named. However, whether anonymous or not, Willis skilfully knits the narrative of the 
photographs together with the images presented in the written records. The method applied to reading the photographs is mirrored in her reading of the texts. The results are nuanced, complex, multi-dimensional depictions of soldiers (and other workers, including women) who fought on both sides of the 'Rebellion.' The act of reporting and imagining the period from the perspective of black soldiers and with the intent of understanding their experience more comprehensively must be understood as a radical act that Willis participates in alongside her readers. Willis demonstrates how self-representation, seen in the letters of the soldiers themselves or in the evidence that they sought out opportunities to be photographed, are critically important to our assessment and understanding of their bravery and quest for citizenship. The narrative of worthiness, of asserting one's citizenship and patriotism, are narratives that continue to be crafted by African American soldiers in subsequent wars, including World War II.

In my own research I am investigating related topics focused upon black soldiers in World War II and therefore Willis's methodology and her conclusions are both stimulating and helpful. One aspect of my research engages with the archive left by my late father which encompasses his overseas service as an army corporal from 1943 to 1945 . Another aspect of my work uses the same archive to compare representations of patriotism in World War II, The Cold War and in the post-Civil Rights era. Both strands of research are concerned with definitional and intersectional questions of family, archives and racialisation. For instance, how do African American archival projects both create and critique notions of racial family? Arturo Alfonso Schomburg and Michel Foucault provide important theoretical grounding to such questions. My concerns with the definition, status and power of archives and archival research, intersects with several of the points raised by Willis regarding representations of gender, masculinity and citizenship. As Willis's work and the work of others show, soldiers in the military and their familial networks are unique but are also a subset of the larger African American and black diasporan populations who continue to be defined and contained 
by processes of racialisation and discrimination in the twenty-first century. ${ }^{1}$ In its multi-dimensional approach 'The Black Civil War Soldier' is an important addition to this ongoing scholarly and popular conversation.

The multi-dimensional archive I am working with was preserved by my grandparents and my parents and is comprised of photographs, clothing, telegrams, service medals, letters and journalism and it dates from 1943 to 1997. Despite its treasures, the archive is inevitably partial and incomplete. In considering how to account for its gaps, I believe Willis' example of using African American literature (she opens her essay with Frederick Douglass) is the same means by which I might provide a rich contextual resource for my father's archive. African American literature (both fiction and nonfiction) has long played a key role in contesting received histories of black people and as such can be understood as an imaginative archive. Later in this essay I explore this idea further, using the poetry of Gwendolyn Brooks. When Willis announces her intention is to 'engage the reader in the expressive act of portrait making and how dreams of freedom and emancipation could be both imagined and made possible through a photographer's lens' (2), phrases such as 'expressive act,' 'dreams of freedom' and 'imagined' signal another vantage point from which we might consider archival work in African American Studies: ontological and epistemological contexts. Willis's

\footnotetext{
${ }^{1}$ Recent scholarship has delved into other aspects of creative imagining, archives and African American war experiences. See Celeste Marie Bernier, Characters of Blood: Black Heroism in the Transatlantic Imagination (University of Virginia Press, 2012); Celeste Marie Bernier, Suffering and Sunset: World War I in the Art and Life of Horace Pippin (Temple University Press 2015); and Jennifer C. James, A Freedom Bought With Blood: African American War Literature from the Civil War to World War II (Chapel Hill: University of North Carolina Press, 2007). In fiction, Half Blood Blues by Esi Edugyan (2011) is particularly skilful in its representation of complex racialized experiences of World War II, and, like Fred Moten's In The Break: The Aesthetics of the Black Radical Tradition (Minneapolis: University of Minnesota Press, 2003), Half-Blood Blues reminds us of the centrality of improvisation to representations and understandings of black diasporan narratives. Finally, Hans Massaquoi's autobiography Destined to Witness: Growing Up Black in Nazi Germany (Harper Collins, 1999) emphatically disrupts singular notions of Afro-German and Black U.S. experiences of World War II.
} 
method of using a variety of materials to decipher and gain context for photographs of unidentified Civil War soldiers is an enactment of the Foucauldian notion that archives are not just places where information is held but which also actively produce meaning. ${ }^{2}$ I see her work as not just the interpretation of archival materials but as a creation of a new archive. This new archive asserts vital links that exist between African American material culture, the archives of state and military power and the imaginative archive of African American literature.

Willis's frameworks for imagining and telling the experience of the black Civil War soldier, her conjoining of domestic and public modes for these articulations are announced in her two epigraphs. The first epigraph comes from one of Frederick Douglass's speeches about the Civil War and the second epigraph comes from a soldier in that conflict, Sergeant Charles Brown. These words frame the photographic and written records presented by Willis and signal the methodological practice of using African American literature - broadly defined-- to both enliven and interpret the archival materials under discussion. Willis's 'portraits' draw from all of these sources and, her epigraphs suggest, the photographic and narrative portraits are mutually dependent and inform one another. Douglass's powerful rhetoric imagines for his listener a typical black male soldier entering the conflict. He makes plain how the physical act and psychological consequence of wearing the military uniform effects in that soldier a sense that he has every right to citizenship of the United States. The photographs and Willis's interpretation of their meanings lend additional weight to Douglass's ideas and to Sergeant Brown's vow to 'fight as long as a star can be seen.'

The intersections of self and nation, patriotism and frustration, public and private, highlighted in the essay and its epigraphs were differently calibrated but no less acute for the black American soldier in

\footnotetext{
${ }^{2}$ Michel Foucault, The Archaeology of Knowledge and the Discourse on Language (Abingdon: Routledge Classics, 1969/2002).
} 
1941, the year America entered World War II. The Thirteenth Amendment to the U.S. constitution (1865) outlawed slavery and the Fourteenth Amendment (1868) conferred citizenship on ex-slaves and indeed anyone born or naturalized in the United States. Yet, black people who volunteered for or were drafted into the armed forces in the 1940 s entered a service riven by racial discrimination and one which was officially segregated. ${ }^{3}$ Their experiences have been captured in documentary histories, films, photographs and in African American poetry, fiction, drama and autobiography, and plays. Literary scholar, Jennifer C. James, in her study of African American War Literature from the Civil War to World War II, sees a straight line from nineteenth century advocates of African American 'manhood rights', like Frederick Douglass, to African American war novels written in the twentieth century by authors such as John Oliver Killens and Chester Himes. James contends, ...the idea of manhood in these [later] works is equally bound to the liberation, citizenship, and leadership of black men. Accordingly, many of these novels include depictions of the front that serve as a backdrop against which the black soldier-citizen can demonstrate his courage' ${ }^{4}$

James continues, by stating that 'the main concern' of what she calls the black masculinist war novel of the twentieth century, 'is to present the black soldier citizen as the epitome of manliness honourable, ethical, powerful, virile'. ${ }^{5}$ This analysis is not very different from Willis's scrutiny of nineteenth century photographs of black soldiers. The impulse that Willis identifies as a motivating factor in Civil War photographs continues into the twentieth century in the literature and stresses a continuity of concerns, articulated in both fictional and historical contexts, in private letters as well as in public pronouncements.

\footnotetext{
${ }^{3}$ See Phillip McGuire, Taps for a Jim Crow Army: Letters from Black Soldiers in World War II (Santa Barbara and Oxford: ABC-Clio, 1983) 79-80.

${ }^{4}$ Jennifer C. James, A Freedom Bought With Blood: African American War Literature from the Civil War to World War II (Chapel Hill: University of North Carolina Press, 2007) 19.

${ }^{5}$ Ibid.
} 
It is notable that James calls attention to the 'backdrop' of the war front in various fictional literary depictions. The language of staging and posing offers a further link between the literary and the photographic and between the public and the private. 'Backdrop' is the most appropriate phrasing for James's literary discussion but it also evokes the literal backdrops used in the Civil War photography studios, as discussed by Willis, and which effected a similar image of competent, ablebodied black men as integral to the fabric and strength of the U.S. military. This shared language across literary and photographic texts of black soldiers underscores the need to consider such texts in conversation with one another as Willis does in her essay and as I do in my examination of my father's archives. Gwendolyn Brooks makes innovative use of poetic form to shift the discussion of war and black manhood in a different direction at mid-century. Brooks' poetic portraits of black World War II soldiers extend the discourse of Douglass's speeches in the $19^{\text {th }}$ century yet hers is an understanding of black soldier-hood, patriotism and battle-readiness which emphasises unknowability and vulnerability.

In a series of war poems titled 'gay chaps at the bar' published in 1945, Brooks offers a new vision of masculinity in her portrayal of black World War II soldiers. Both striking and disconcerting, the poems are based upon letters sent by black soldiers abroad to Brooks at The Chicago Defender, where she was a columnist. (The title for the series is lifted directly from one such letter she received. ${ }^{6}$ ) In these word portraits she captures 'backdrops' to the World War II soldier that are not analogous to the patriotic tableaux of a photographer's studio; she brings to life the domestic imaginary in dialogue with the soldiers' often traumatic experiences. Collectively, the poems push readers to re-think the narrative of belonging and desire for citizenship, and to re-think the 'worthiness' narrative that remained attached to black soldiers. Brooks' contribution to the multidimensional project of telling the story of black American soldiers is defined in large part by her

\footnotetext{
${ }^{6}$ Gwendolyn Brooks, Selected Poems (New York, Harper and Row, 1963) 22.
} 
method of weaving the soldiers' letters into her poems. In giving voice to black soldiers' 'other' stories from the front, in linking private voices and communal concerns, Brooks creates portraits with her poems which exist in contrapuntal harmony with Willis's work. ${ }^{7}$ A close examination of 'looking', the fourth of Brooks' war sonnets, reveals how this is so.

In 'looking,' one of the first images the reader is presented with is Brooks' location of masculinity in both private and public spaces:

You have no word for soldiers to enjoy The feel of, as an apple, and to chew With masculine satisfaction. Not "good-by!" "Come back!" or "careful!" Look and let him go. "Good-by!" is brutal, and "come back!" the raw Insistence of an idle desperation Since could he favour he would favour now. He will be "careful!" if he has permission. Looking is better. At the dissolution Grab greatly with the eye, crush in a steel Of study - Even that is in vain. Expression, The touch or look or word, will little avail, The brawniest will not beat back the storm Nor the heaviest haul your little boy from harm. ${ }^{8}$

In its first six lines the speaker, a soldier who clearly knows the realities of war, offers sober advice to parent(s), and acknowledges the domestic space of home, without needing to name it. The home space is conveyed by the heavy, brief sentence 'Look and let him go' while the speaker's voice declares the inadequacy of words. The parents' hopeful sentiments for the safe return of their 'little' boy are scorned as 'idle desperation'. As the poem develops, Brooks imbues her lines with layered meanings that capture the plight and the emotions of the black soldier as well as the anxieties of those on the home front. The tone of the poem careens from crisp declarations to abject laments, as in line 8, 'He will be "careful!" if he has permission' which reminds the reader how

\footnotetext{
${ }^{7}$ Gwendolyn Brooks, Report From Part One (Detroit, Michigan: Broadside Press, 1972), 156.

8 Brooks, Selected Poems, 24.
} 
very few black soldiers were in combat units, despite wanting to fight. ${ }^{9}$ The poem's closing lines return to the inadequacy of words to capture the grim realities of warfare. These final lines are Brooks' 'attempt to give voice to' bodies which are 'visibly physically broken. ${ }^{10}$ In making these assertions Brooks narrates a different part of the story that Willis introduces in Civil War contexts. Willis's scholarship successfully makes black soldiers' bodies visible; her injury-free bodies radiate hope and possibility. In contrast Brooks' poems push the reader to imagine what they rather not see. Brooks does not shy away from troubling discourses of the body in war, and of the images of nonheroic bodies, such as those in 'looking'. Ultimately, the violence of war transcends words and expression: 'Expression, the touch or look or word, will little avail' and death and dismemberment might find any soldier, regardless of the strength of sentiment expressed by those who love him. ${ }^{11}$

Where words might be inadequate, Brooks offers her reader another avenue for interpretation with her sculpting of the sonnet form. While the sonnet is a structure which Brooks frequently used, poet and literary scholar Elizabeth Alexander notes that Brooks often defied convention and 'worked with expert subtlety to make the sonnet her own. ${ }^{12}$ With the poems of 'gay chaps at the bar' Brooks does just this and creates 'off-rhyme sonnets' for what she termed 'an off-rhyme situation' referring to the war and the paradoxically cruel situation of black soldiers at the front. ${ }^{13}$ Clearly the 'offrhyme situation' refers to not just the horrors of war but also to the racial bigotry and hatred that

\footnotetext{
${ }^{9}$ Phillip McGuire writes, 'Although they were assigned to every branch of the services opened to them, the Army confined most of the [black] troops to the Service forces...These assignment practices resulted in blacks being trained almost exclusively for noncombat functions as laborers, stevedores, and servants' (Taps for $a$ Jim Crow Army, 59).

${ }^{10}$ Jennifer C. James, A Freedom Bought with Blood, 239.

${ }^{11}$ The poem's final two lines also invoke Doris 'Dorie' Miller, an African American war hero of the Pearl Harbour attack, who did 'beat back the storm' of Japanese airstrikes and did 'haul' others from harm, and who was particularly brawny, but who died in a later battle nonetheless. In 'Negro Hero', a poem written at the same time but that sits outside of the 'gay chaps at the bar' series, Brooks provides a direct response to the iconography that circulated in 1942 of Miller.

${ }^{12}$ Elizabeth Alexander ed. 'Introduction' The Essential Gwendolyn Brooks, (U.S.A.: Literary Classics of the United States, 2005) xviii.

${ }^{13}$ Gwendolyn Brooks, Report, 156.
} 
permeated black life in the military and outside of it too. Brooks' war sonnets, Alexander notes, 'made subtle breaks so that her poetics underscore and enact what she speaks of'. ${ }^{14}$ In image, form, and philosophy then, 'looking' as representative of Brooks' war poems, shares much in common with the photography presented in 'The Black Civil War Soldier.' Early in her essay Willis makes plain that hers is not a triumphalist project. Like the 'off-rhyme situation' which Brooks observes in World War II, Willis also attends to 'the low points for black soldiers in the war, from inequities in pay to discriminatory practices in the field...to the shared experiences of all soldiers' (2). Furthermore, Willis calls attention to black soldiers who, like Brooks with the sonnet form, were eager to mould the medium of photography to their purposes. Willis writes 'both the soldiers and the photographers were invested in how their images were made, used, displayed and distributed' (7). These images, like Brooks' poetic portraits, broadcast multiple and complex narratives of black soldier-hood.

Both Willis and Brooks display strategic, aesthetic manoeuvres that collectively enlarge our understanding of black U.S. patriotism. In different modes, they each demonstrate the importance of considering black military service, discourses of masculinity and worthiness, and the inexorable horrors of war in multivalent registers. I have paired them in my discussion in part because of the parallels in their method including their use of multi-dimensional and imaginative archives to tell their soldiers' stories and present their soldiers' unflinching images. In following their example as I develop my projects on World War II, archives and racialisation I will continue to ask the questions that Willis and Brooks engage with so beautifully: how to negotiate public and private realms of representation, how to creatively address the partiality of archives, and how to contribute to the production of archival knowledge that does justice to the people whose stories I am hoping to tell.

\footnotetext{
14 Elizabeth Alexander ed. 'Introduction,' xviii.
} 


\section{Bibliography}

Alexander, Elizabeth ed. 'Introduction' The Essential Gwendolyn Brooks, (U.S.A.: Literary Classics of the United States, 2005).

Brooks, Gwendolyn Report From Part One (Detroit Michigan: Broadside Press, 1972).

Brooks, Gwendolyn, Selected Poems (New York, Harper and Row, 1963).

Bernier, Celeste Marie Characters of Blood: Black Heroism in the Transatlantic Imagination (University of Virginia Press, 2012).

Bernier, Celeste Marie Suffering and Sunset: World War I in the Art and Life of Horace Pippin (Temple University Press 2015).

Foucault, Michel The Archaeology of Knowledge and the Discourse on Language. (Abingdon: Routledge, 1969/2002).

James, Jennifer C. A Freedom Bought With Blood: African American War Literature from the Civil War to World War II (Chapel Hill: University of North Carolina Press, 2007).

McGuire, Phillip, Taps for a Jim Crow Army: Letters from Black Soldiers in World War II (Santa Barbara and Oxford: ABC-Clio, 1983). 